if not "global" in character, prior to postmodernity (D. Chakrabarty, "Provincializing Europe: Postcoloniality and the critique of history," Cultural Studies, 6.3 [1992]: 337-57). This is particularly troublesome as Galli utilizes a genealogical approach in mapping the evolution of political spaces to one that takes a global character. To uncritically use Europe as central historical referent limits the book's potential for breaking away from modernity's epistemology and providing an alternative politics for knowledge production. Nevertheless, this book puts forward an exciting contribution to the discussion on the relevance of modernity's conceptual categories in the postmodern condition-a suitable reading for both students and scholars of politics, sociology, and political geography.

NICOLE CURATO

University of the Philippines <nccurato@upd.edu.ph>

\title{
The Promise of Happiness
}

Durham: Duke University Press, 2010. 315 pp.

The Promise of Happiness begins with a discussion of what Sara Ahmed called "the happiness turn" in economics and positive psychology. Books with titles like The Happiness Formula and Happiness and Economics offer to measure the happiness of individuals, groups, or entire nationstates. According to Ahmed, these books expose the performativity of happiness. As both a word and a desired state, happiness does things. Positive psychology, for example, involves "the instrumentalization of happiness as a technique" (10), reifying certain routes to happiness; economic happiness data locates and stratifies the happy over and in relation to unhappy others. Both discourses are presided over by some "generalized culture of expertise" (9), contributing to the self-work that Nikolas Rose (Governing the Soul: The Shaping of the Private Self; London: Free Association Books, 1999) describes as the government of the soul. "A happy life, a good life," Ahmed argues, "involves the regulation of desire. It is not simply that we desire happiness but that happiness is imagined as what you get in return for desiring well" (37). A key objective of The Promise of Happiness is to describe how this desiring well functions as a technology of social regulation through 
the privileging of, and steering of persons toward, certain objects (the family; children), certain lifestyles (monogamy), and certain lifenarratives (citizenship; marriage), even if the happiness promised by the proximity to those objects always remains in some elusive or unobtainable future. The promise of happiness encourages us to want certain objects and to prioritize our desires in particular ways. This prioritization is something of an affective habitus, a "technology of self-production" (43).

Early in the book, Ahmed discusses the part of the happiness injunction that is the responsibility to be happy for others, a feature that binds happiness causes and happiness trajectories to structures of sociality. Our freedom to pursue these objects and the promise of happiness that they portend, she argues, is in fact a directive: certain states and objects and structural arrangements are already attributed as "happiness causes" (7), and our orientation towards them is a social and political mandate that favors some horizons of personhood and sociality and forecloses on others. In some of her early examples (the bride unhappy on her wedding day; the individual in a laughing crowd who feels shame or disgust for not sharing the joke), the happiness injunction and the gaps it produces appears as a universal condition. However, some social groups are aware of the underside of the happiness promise more keenly than others. Ahmed calls these people "affect aliens", and it is around three key case studies of affective alienation"the feminist killjoy," the "the unhappy queer," and "the melancholic migrant"-that her investigation of the happiness injunction gets fleshed out. There are undoubtedly others, but these particular case studies provide a rich cultural archive of unhappiness texts (novels and films, for the most part) that enable Ahmed to identify the gap between the promise of happiness and how one is actually affected by the objects that promise happiness.

Ahmed finds unhappiness archives in a range of places, some predictable, others less so. Radclyffe Hall's The Well of Loneliness (1928), for example, is one of-if not the-classic novels of queer melancholy. Ahmed's take on the novel's "unhousing" of the queer is a more politically energizing reading than, for example, Heather Love's ("Spoiled Identity: Radclyffe Hall's Unwanted Being," in Feeling Backward: Loss and the Politics of Queer History, 100-128; Cambridge, MA: Harvard University Press, 2007) recent reflections on unwantedness and spoiled identity in the novel. Love's work is nonetheless energizing for Ahmed, whose chapter on Unhappy 
Queers is ultimately interested in reflecting on the political force of being "happily queer." Being happily queer, which Ahmed finds in the "bad object choices" described in Rita Mae Brown's novel Rubyfruit Jungle (1973), may cause unhappiness but moves "beyond the straight lines of happiness scripts" (115). This chapter also makes a significant contribution to discussions of the affective politics of homonormativity and of the ambivalence of certain (normative) happiness promises in an examination of the film If These Walls Could Talk 2 (2000).

In "Melancholic Migrants," Ahmed shows how the history of empire as a form of forced happiness haunts postcolonial societies. Integration and assimilation are happiness injunctions that foreclose certain cultural attachments and demand that we forget the colonial past. For example, the happiness duty of the Asian migrant in contemporary Britain is, she argues, "continuous with the happiness duty of the natives in the colonial mission" who "must become (more) British in order to be recognized as subjects of empire"; "in a contemporary context, it is migrants who must become (more) British in order to be recognized as citizens of the nation. Citizenship now requires a test: we might speculate that this test is a happiness test" (130). A close analysis of the films Bend it Like Beckham (2002) and East is East (1999) present the migrant as a subject expected to perform the duty of happiness through a renunciation of the (unhappy) colonial past and the racist present.

In all of these cases, the unhappiness of the affect alien functions to expose the ideological loadedness of the happiness imperative. The affect alien's capacity to foreground and instantiate discomfort-as in the case of the killjoy feminist who points out the unhappiness of the "happy housewife" — can be a productive, radicalizing force. Ahmed's feminist killjoys are mostly literary protagonists (George Eliot's Maggie Tulliver, Virginia Woolf's Clarissa Dalloway, and Toni Morrison's Pecola and Claudia, for example). Through these figures, the archive of feminist consciousness raising (re)emerges as an archive made radical by its willingness to be proximate to unhappiness-to literally "kill joy." Once exposed, the social networks concealed and congealed around the promise of happiness allow us to ask "other questions about life, about what we want from life, or what we want life to become" (218).

There is a long history of ideas about happiness in philosophical and political theory, and Ahmed walks the reader through some of this history's salient moments-from passion in Descartes and affect 
in Spinoza, to Nietzsche's critique of utilitarianism. There is such a richness of this material throughout the book that it's hard to say who or which traditions are most important. A recurrence of certain ideas and protagonists associated with the recent affective turn in cultural studies (Lauren Berlant, Heather Love, Ann Cvetcovitch, Eve Sedgwick, and David Eng, for example) helps to locate The Promise of Happiness within the particular sub-field of affect studies. However, Ahmed is equally reliant on (and equally comfortable) with Audre Lorde (among other black feminists), Lee Edelman (among other queer theorists), and Giles Deleuze (among other earlier theorists of affect), as she is on Plato's Republic. The book is so much more than a tour through these ideas, and yet, I don't think it's an insult to describe it as something of a Sophie's World of happiness philosophy, because this may be one of its core functions for readers in feminist cultural studies, critical race theory, disability studies, and queer studies, whose methods and theoretical knowledge often favors the textual and the historical. For those types of readers, The Promise of Happiness will serve as a useful introduction to the philosophies underpinning contemporary theoretical approaches to thinking about sociality, subjectivity, affect, and the governance of life. But The Promise of Happiness is much more than Happiness Philosophy 101, for what Ahmed offers here is a deeply resonant but also strongly reasoned theory of how history and ideology become affect. The happiness imperative as an illustrative case study is at once bold and sweeping because, put simply, happiness is so hard to argue against.

DION KAGAN

University of Melbourne <dkagan@unimelb.edu.au>

MARIA DO MAR CASTRO VERALA, NIKITA DHAWAN, AND

ANTKE ENGEL, EDS.

\section{Hegemony and Heteronormativity}

Revisiting "The Political" in Queer Politics

Farnham; Burlington, VT: Ashgate, 2011. 224 pp.

Maria do Mar Castro Varela, Nikita Dhawan and Antke Engel's Hegemony and Heteronormativity presents a very complex analysis of "the political" in queer politics. From the outset, the editors define the 